\title{
ANALISIS PERLINDUNGAN HUKUM TERHADAP NASABAH DALAM TRANSAKSI E-BANKING DI INDONESIA
}

\author{
Rizqi Musrifah ${ }^{1}$, Satria Sukananda ${ }^{2}$ \\ Fakultas Hukum Universitas Muhammadiyah Yogyakarta (UMY) Yogyakarta \\ artisukananda@gmail.com
}

\begin{abstract}
Currently, banks have relied on information technology in carrying out their activities through e-banking. E-banking refers to any services for bank customers to conduct banking transactions through electronic media. The development of science also has a negative impact which leads to financial losses to bank customers. Therefore, customers must be protected by laws and regulations as well as the bank's operational security system. The purpose of this study is to analyze the legal protection for customers in ebanking transactions in Indonesia. This study uses normative legal research methods. This study will examine the principles, legal concepts and related laws and regulations. The results of the study indicate that bank customers are protected by the provisions that must be carried out by banks in relation to the implementation of electronic banking services, namely in the Law, Financial Services Authority Regulations, Bank Indonesia Regulations. The problem between the bank and the customer can be solved through alternative dispute resolution and court.
\end{abstract}

Keyword: Banks, Legal Protection, Customer E-Banking

\begin{abstract}
ABSTRAK
Saat ini perbankan sudah mengandalkan terknologi informasi dalam kegiatannya yaitu berupa e-banking. E-banking merupakan layanan bagi nasabah bank untuk melakukan transaksi perbankan melalui media elektronik. Perkembangan ilmu pengetahuan juga membawa dampak negatif yaitu menimbulkan kerugian secara finansial kepada nasabah bank. Oleh karena itu nasabah harus dilindungi oleh peraturan perundang-undangan serta sistem keamanan operasional bank. Tujuan dari penelitian ini adalah menganalisis bagaimanakah perlindungan hukum terhadap nasabah dalam transaksi e-banking di Indonesia. Penelitian ini menggunakan metode penelitian hukum normatif. Penelitian ini akan mengkaji asas-asas, konsep-konsep hukum serta peraturan perundang-undangan yang terkait. Hasil penelitian menunjukkan bahwa nasabah bank dilindungi dengan adanya ketentuan yang harus dilaksanakan bank dalam kaitannya dengan penyelenggaraan layanan perbankan elektronik yaitu dalam Undang-Undang, Peraturan Otoritas Jasa Keuangan, Peraturan Bank Indonesia. Untuk penyelesaian masalah antara bank dengan nasabah dapat dilakukan dengan cara alternatif penyelesaian sengketa dan pengadilan.
\end{abstract}

Kata Kunci : Perbankan, Perlindungan Hukum, Nasabah E-banking.

\footnotetext{
${ }^{1}$ Submit: 22.12.2018 Edting-1: 22.12.2018 Review-1: 24.12.2018 Review-2: 24.12.2018 Editing2: 1.1.2019 Production:1.1.2019
} 


\section{Pendahuluan}

Saat ini dengan adanya fasilitas e-banking dapat memberikan kemudahan bagi masyarakat dalam melakukan transaksi keuangan tanpa harus datang ke bank, khususnya bagi para pengguna bisnis berskala besar yang memiliki kebutuhan akan sistem yang cost-effective, leluasa, aman, automated, terpadu dan handal tanpa harus terkendala dengan ruang dan waktu. $^{2}$ Hal tersebut tentunya dapat menjadi sarana yang efektif bagi para nasabah yang tinggal di kota-kota besar dengan tingkat kemacetan lalu lintas yang tinggi. ${ }^{3}$

Secara objektif, dalam mengelola setiap jasa keuangan yang ditawarkan kepada nasabah, bank memiliki prinsip kehati-hatian yang tinggi, namun seiring dengan perkembangan zaman, kemajuan di bidang ilmu pengetahuan dan teknologi telekomunikasi tidak hanya berdampak positif tetapi juga menimbulkan dampak negatif. Banyak pihak yang tidak bertanggung jawab memanfaatkan kemajuan teknologi informasi untuk melakukan tindak kejahatan. Hal tersebut diperburuk dengan tingkat keamanan internet perbankan nasional yang ternyata tidaklah cukup untuk dikatakan aman dari pembobolan para peretas.

Hal ini sesuai dengan pemberitaan dalam beberapa media elektronik, bahwa berdasarkan pantauan Tim Insiden Keamanan Internet dan Infrastruktur Indonesia (Indonesian Security Incident Response Team on Internet Infrastructure/ ID-SIRTII), upaya gangguan terhadap sistem $i$-banking bisa mencapai puluhan kali per situs dalam satu hari. Titik yang paling mudah diserang dalam sistem perbankan internet adalah nasabah. Selain karena pengamanan sistem di bank yang kurang baik, komputer yang digunakan nasabah umumnya dipakai untuk berbagai hal sehingga rentan diserang dan dikontrol pihak lain. Sebagai contoh berikut dipaparkan beberapa kasus $e$ banking yang pernah terjadi di Indnonesia antara lain :

\footnotetext{
${ }^{2}$ Soetarto dan M. Nasir, "Teknologi E-Banking di Kalangan Smart Customer : Kasus di Kota Solo", Paper Conference Fakultas Ekonomi Universitas Muhammadiyah Solo, 2008, hlm. 171. ${ }^{3}$ Ibid.
} 
Dalam Kompas.com disebutkan bahwa terjadi pembobolan beberapa dana nasabah pada tiga bank besar di Indonesia dengan modus menggunakan software internet banking, modus kejahatan ini diklaim telah menimbulkan kerugian mencapai Rp 130 Miliar. $^{4}$

Selanjutnya disebutkan bahwa ada sebuah informasi yang beredar di media sosial tentang seorang nasabah Bank Central Asia yang merasa bahwa rekeningnya dibobol setelah dia berulang kali gagal melakukan transaksi ebanking Bank Central Asia. Saat nasabah tersebut melakukan login, muncul tampilan "sinkronisasi token" dan menyebabkan komputer hang. Setelah restart dan kembali login ke Internet Banking Bank Central Asia, nasabah mendapati uangnya telah berkurang sebesar Rp 13 juta. ${ }^{5}$ Hal ini tentunya sangat merugikan bagi nasabah karena uang yang berada di rekening mereka dapat hilang begitu saja.

Dalam CNN Indonesia juga disebutkan bahwa terjadi permasalahan dalam penggunaan e-banking oleh seorang nasabah yang bernama Tjho Winarto. ${ }^{6}$ Permasalahan tersebut mengakibatkan hilangnya uang sebanyak Rp 245.000.000,00 dari tabungannya. Uang tersebut terindikasi ditransfer ke beberapa bank yang ada di Indonesia. Dalam kasus ini pihak bank justru mengeluarkan statement bahwa transfer uang tersebut sudah melalui prosedur transaksi yang valid dan otentik.

Berdasarkan uraian kasus di atas, maka diketahui bahwa perlindungan terhadap nasabah perbankan merupakan permasalahan yang sampai saat ini belum mendapat tempat yang baik di dalam sistem perbankan nasional. Padahal dalam dunia perbankan, pihak nasabah merupakan unsur yang sangat berperan, sehingga mati hidupnya dunia perbankan sangat bergantung pada

\footnotetext{
${ }^{4}$ http://bisniskeuangan.kompas.com/read/2015/04/15/113500326/Ini.Modus.Pembobolan. Rekening.Nasabah.Melalui.e-Banking, diakses pada tanggal 19 Agustus 2018

${ }^{5} \mathrm{http}: / /$ bisniskeuangan.kompas.com/read/2015/03/04/144553726/BCA.Minta.Nasabah.Was padai.Sinkronisasi.Token.saat.Membuka.Internet.Banking, diakses pada tanggal 19 Agustus 2018

${ }^{6}$ http://www.cnnindonesia.com/ekonomi/20150306103528-78-37161/rekening-dibobolkasus-bank-permata-lanjut-di-pengadilan/, diakses pada tanggal 19 Agustus 2018
} 
masyarakat atau nasabah itu sendiri. ${ }^{7}$ Namun, selama ini belum ada kejelasan mengenai perlindungan hukum terhadap nasabah bank dalam bertransaksi melalui e-banking.

Kedudukan nasabah bank selama ini masih dianggap lemah dan dalam posisi yang kurang diuntungkan apabila terjadi kasus-kasus hukum, atau kasus perselisihan antara bank dengan nasabahnya. ${ }^{8}$ Posisi Konsumen dimana dalam hal ini adalah nasabah sebagai pihak yang lemah juga diakui secara internasional sebagimana tercermin dalam Resolusi Majelis Umum Persatuan Bangsa Bangsa No.A/RES/39/248 tahun 1985, tentang guidelines for consumer protection, yang menghendaki agar konsumen dimanapun mereka berada, dari segala bangsa, mempunyai hak-hak dasar tertentu terlepas dari status sosialnya. ${ }^{9}$

Adapun yang dimaksud dengan hak-hak dasar tersebut antara lain adalah hak untuk mendapatkan informasi yang jelas, benar, dan jujur, hak untuk mendapatkan keamanan dan keselamatan, hak untuk memilih, hak untuk didengar, hak untuk mendapatkan ganti rugi, hak untuk mendapatkan kebutuhan dasar manusia. Persatuan Bangsa-Bangsa (PBB) menghimbau seluruh anggotanya untuk memberlakukan hak-hak konsumen tersebut di negaranya masing-masing.

E-banking merupakan fasilitas yang diperoleh nasabah bank, sehingga hubungan hukum antara bank dengan pengguna e-banking merupakan hubungan antara bank dengan nasabah baik sebagai debitur maupun sebagai kreditur. Dasar dari hubungan tersebut adalah perjanjian baik perjanjian penyimpanan dana di bank maupun perjanjian hutang atau kredit dengan bank. Hal ini tentunya semakin mengaburkan perlindungan hukum terhadap nasabah dalam bertransaksi melalui $e$-banking karena dalam perjanjian antara nasabah

\footnotetext{
${ }^{7}$ Mahesa Jati Kusuma, Hukum Perlindungan Nabah Bank : Upaya Hukum Melindungi Nasabah Bank Terhadap Tindak Kejahatan ITE di Indonesia, Jakarta, Nusa Media, 2012, hlm.74.

${ }^{8}$ Ibid. hlm.73.

9 Gunawan Widjaja dan Ahmad Yani, Hukum Tentang Perlindungan Konsumen, Jakarta. PT Gramedia Pustaka Utama, 2003, hlm. 48.
} 
dan bank terdapat klausula eksonerasi. Klausula eksonerasi sendiri berarti klausula yang berisi pembatasan pertanggunganjawaban dari kreditur. ${ }^{10}$

Secara sederhana klausula eksonerasi ini diartikan sebagai klausula pengecualian kewajiban atau tanggung jawab dalam perjanjian dan klausula yang mengandung kondisi membatasi atau bahkan menghapus sama sekali tanggung jawab yang semestinya dibebankan kepada salah satu pihak. ${ }^{11}$ Permasalahan juga menjadi timbul ketika dalam prakteknya pihak bank justru memanfaatkan hal tersebut untuk menekan nasabah dengan membuat klausulklausul yang memberatkan itu, yang disebut sebagai klausula eksonerasi sehingga yang terjadi adalah ketidakseimbangan posisi tawar menawar diantara para pihak. ${ }^{12}$ Padahal dalam Undang-Undang Nomor 8 Tahun 1999 tentang Perlindungan Konsumen yaitu dalam Pasal 4 huruf a sudah jelas disebutkan bahwa konsumen mempunyai hak atas kenyamanan, keamanan, dan keselamatan dalam mengkonsumsi barang dan/atau jasa. ${ }^{13}$

Selain itu dalam Pasal 29 ayat (4) Undang-Undang Nomor 10 Tahun 1998 tentang Perubahan Atas Undang-Undang Nomor 7 Tahun 1992 tentang Perbankan juga disebutkan, untuk kepentingan nasabah, bank menyediakan informasi mengenai kemungkinan timbulnya risiko kerugian bagi transaksi nasabah yang dilakukan melalui bank. Kemudian dalam Peraturan Otoritas Jasa Keuangan Nomor 1/POJK.07/2013 tentang Perlindungan Konsumen Sektor Jasa Keuangan juga ditentukan bahwa bank memiliki kewajiban untuk memberitahukan risiko pada nasabah sebagaimana tercantum dalam Pasal 8 ayat (1) dan (2) nya yang menyatakan :

"Pelaku Usaha Jasa Keuangan wajib menyusun dan menyediakan ringkasan informasi produk dan/atau layanan. Ringkasan informasi produk dan/atau layanan yang dimaksud wajib dibuat secara tertulis,

\footnotetext{
${ }^{10}$ Sutan Remy Sjahdeni, Kebebasan Berkontrak Dan Perlindungan Yang Seimbang Bagi Para Pihak Dalam Perjanjian Kredit Bank di Indonesia, Jakarta, PT Pustaka Utama Grafitri, 2009, hlm. 83.

${ }^{11}$ Diana Simanjuntak, "Tinjauan Hukum Perlindungan Konsumen Terhadap Perjanjian Kredit Bank", Legal Opinion, Volume IV Nomor I , 2016, hlm. 3.

${ }^{12}$ Ibid.

${ }^{13}$ Lihat Pasal 4 Undang-Undang Nomor 8 Tahun 1999 tentang Perlindungan Konsumen
} 
sekurang-kurangnya memuat manfaat, risiko, dan biaya produk dan/atau layanan serta syarat dan ketentuan". ${ }^{14}$

Dalam Pasal 23 Peraturan Otoritas Jasa Keuangan Nomor 38 /POJK.03/2016 Tentang Penerapan Manajemen Risiko Dalam Penggunaan Teknologi Informasi Oleh Bank Umum disebutkan bahwa bank wajib menyelenggarakan Pemrosesan Transaksi Berbasis Teknologi Informasi di wilayah Indonesia dengan memenuhi prinsip kehati-hatian, memperhatikan aspek perlindungan kepada nasabah dan mendapat persetujuan dari Otoritas Jasa Keuangan, sedangkan dalam Pasal 28 nya disebutkan bahwa bank harus memiliki program perlindungan dan edukasi kepada nasabah dalam layanan perbankan elektronik.

Meskipun demikian, faktanya tetap saja kasus-kasus yang terjadi terhadap penggunaan e-banking semakin lama semakin luas dan semakin beragam modusnya. Nasabah terkadang juga kurang hati-hati dalam bersikap sehingga mudah mengalami kejahatan e-banking yang ada. Kurangnya transparansi informasi dan edukasi yang diberikan pihak bank juga akan memicu semakin tingginya tingkat kerugian nasabah dalam menggunakan $e$ banking. Bank harusnya transparan dalam menyelenggarakan Good Corporate Governance dan menginformasikan kepada publik secara konsisten. ${ }^{15}$ Selain itu bank secara berkesinambungan harus melaksanakan edukasi kepada nasabah mengenai kegiatan operasional maupun produk dan jasa bank untuk menghindari timbulnya informasi yang menyesatkan dan merugikan nasabah. ${ }^{16}$

Berdasarkan uraian di atas, maka nasabah bank perlu mendapatkan kepastian perlindungan hukum yang didapatkan saat bertransaksi melalui $e$ banking. Selain itu juga perlu adanya informasi mengenai penyelesaian yang dapat ditempuh oleh pihak nasabah bank jika merasa dirugikan ketika

\footnotetext{
${ }^{14}$ Lihat Pasal 8 ayat (1) dan (2) Peraturan Otoritas Jasa Keuangan Nomor 1/POJK.07/2013 tentang Perlindungan Konsumen Sektor Jasa Keuangan

${ }^{15}$ Frianto Pandia, Manajemen Dana dan Kesehatan Bank, Jakarta, Rineka Cipta, 2012 hlm. 228.

${ }^{16}$ Ibid.
} 
menggunakan aplikasi e-banking, baik melalui jalur litigasi maupun non litigasi. ${ }^{17}$ Sehingga nasabah tidak akan merasa kebingungan jika terjadi permasalahan dalam bertransaksi melalui e-banking .

Penelitian yang membahas tentang tindak pidana perzinahan secara umum cukup banyak dilakukan oleh para peneliti terdahulu. Berdasarkan hasil penelusuran terhadap beberapa literatur yang telah dilakukan, maka setidaknya ditemukan beberapa literatur yang membahas mengenai permasalahan ini.

Pertama, Tami Rusli dengan judul Perlindungan Hukum Konsumen (Nasabah) Electronic Banking Melalui Anjungan Tunai Mandiri (ATM) pada tahun 2010 yang membahas tentang permasalahan bagaimana bentuk perlindungan hukum terhadap konsumen/nasabah anjungan tunai mandiri. Adapun Hasil penelitian menunjukkan bahwa bentuk perlindungan hukum bagi konsumen (nasabah) yang melakukan electronic banking melalui Anjungan Tunai Mandiri yaitu pemberian keamanan kartu dilakukan dengan mengkombinasikan penggunaan magnetic stripe dengan penggunaan chip (integrated circui"), yang mempunyai kemampuan untuk menyimpan dan/atau memproses data, sehingga pada kartu dapat ditambahkan aplikasi untuk kepentingan pengamanan pemrosesan data transaksi serta peningkatan keamanan mesin Electronic Data Capture (EDC) pada penyedia barang dan/atau jasa (merchant/point of sales), keamanan mesin ATM, dan keamanan pada sistem pendukung dan pemroses transaksi (back end system) yang berada pada penerbit, Acquirer dan/atau third party processor, dilakukan dengan cara menyediakan mesin dan sistem yang dapat memproses kartu dengan teknologi chip sehingga keamanan konsumen terjamin. ${ }^{18}$

Kedua, Satrio Pradana Devanto dan Munawar Kholil dengan judul Perlindungan Hukum Nasabah dalam Transaksi Melalui Internet Banking (Studi di PT Bank Pembangunan Daerah Jawa Timur Tbk) pada tahun 2018 yang membahas permasalahan pelaksanaan perlindungan hukum nasabah

\footnotetext{
${ }^{17}$ Mahesa, Jati Kusuma, op. cit, hlm. 73.

18 Tami Rusli "Perlindungan Hukum Konsumen (Nasabah) Electronic Banking Melalui Anjungan Tunai Mandiri (ATM)", Pranata Hukum, Volume 5, Nomor 2, Juli 2010, hlm. 67
} 
dalam transaksi internet banking di PT. Bank Pembangunan Daerah Jawa Timur Tbk serta pertanggungjawaban hukum dalam transaksi internet banking di PT. Bank pembangunan daerah jawa timur tbk. hasil penelitian ini menyatakan bahwa pelaksanaan perlindungan nasabah pengguna internet banking pada bank jatim dilakukan dengan menekankan ke beberapa aspek yaitu kemanan teknologi internet bangking, pengaduan nasabah dan pendidikan konsumen. dalam hal kemanan teknologi internet banking, bank jatim menerapkan 3 prinsip yaitu prinsip kerahasiaan (confidentiality), integritas (integrity), dan ketersediaan (availability). dalam menjaga keamanan teknologi internte banking, bank jatim menerapkan beberpa teknologi antara lain teknologi ssl yang bertujuan untuk mengacak dan menyandikan informasi agar informasi tersebut tidak disadap oleh pihak yang tidak bertanggung jawab, multifactor identification yang digunakan untuk memeriksa pakah pengguna yang mengakses layanan internet bangking adalah pengguna yang sah, sertifikat elektronik yang digunakan sebagai pembuktian keaslian website yang juga berguna untuk mempertahankan kepercayaan nasabah. pertanggungjawaban yang diterapkan dalam layanan internet banking bank jatim menerapkan prinsip pertanggungjawaban dengan pembatasan. pembatasan tersebut dicantumkan di dalam syarat dan ketentuan yang disetujui nasabah ketika akan melakukan registrasi layanan internet banking. namun jika hanya didasari dengan syarat dan ketentuan tersebut maka akan terlihat sangat tidak adil. karena di dalam syarat dan ketentuan tersebut terlihat adanya posisi yang tidak seimbang antara bank jatim dan nasabah. maka prinsip ini harus diikuti dengan prinsip lain yaitu prinsip selalu bertanggung jawab yang terdapat dalam UU PK. ${ }^{19}$

Mencermati dua penelitian terdahulu di atas, maka dapat dikatakan penelitian ini berbeda dengan kedua penelitian tersebut, adapun unsur kebaruan dalam penelitian ini terletak pada lingkup kajian utama pada masing-

19 Satrio Pradana Devanto dan Munawar Kholil, "Perlindungan Hukum Nasabah dalam Transaksi Melalui Internet Banking (Studi di PT Bank Pembangunan Daerah Jawa Timur Tbk)", Rivat Law Volume 6 Nomor 1 Januari-Juni 2018, hlm. 143 
masing penelitian. Untuk dua penelitian di atas masing-masing memfokuskan pada kajian studi kasus baik di PT Bank Pembangunan Daerah Jawa Timur Tbk ataupun studi di Bank Mandiri, namun berbeda dengan penelitian ini yang lebih luas dalam ruang lingkupnya.

\section{Rumusan Masalah}

2.1. Bagaimana perlindungan hukum terhadap nasabah dalam transaksi ebanking di Indonesia.

2.2. Bagaimana penyelesaian sengketa antara bank dan nasabah dalam transaksi e-banking.

\section{Tujuan Penelitian}

3.1. Untuk mengkaji secara mendalam perlindungan hukum terhadap nasabah dalam transaksi e-banking di Indonesia.

3.2. Untuk menganalisa penyelesaian sengketa antara bank dan nasabah dalam transaksi e-banking.

\section{Metode Penelitian}

\subsection{Jenis Penelitian}

Penelitian ini merupakan penelitian hukum normatif dengan menggunakan studi kepustakaan yaitu penelitian hukum yang meletakkan hukum sebagai sebuah bangunan sistem norma. ${ }^{20}$ Adapun pencarian bahan didasarkan pada bahan hukum yang telah ada baik dalam bentuk peraturan perundangan-undangan maupun karya tulis seperti buku-buku ataupun artikel lain yang terdapat dalam situs internet yang relevan dengan objek penelitian ini. Penelitian hukum normatif ini digunakan dalam memahami perlindungan hukum terhadap nasabah dalam transaksi e-banking di indonesia.

\footnotetext{
${ }^{20}$ Mukti Fajar ND dan Yulianto Achmad, Dualisme Penelitian Hukum Normatif \& Empiris, Yogyakarta: Pustaka Pelajar, 2010, hlm. 34
} 


\subsection{Pendekatan Penelitian}

Pendakatan penelitian ini adalah pendekatan Perundang-undangan (statue approach). Pendekatan perundang-undangan dilakukan dengan mengkaji berbagai peraturan Perundang-undangan atau yurisprudensi terkait isu hukun yang diteliti.

\subsection{Bahan Hukum}

Penelitian ini menggunakan bahan hukum kepustakaan yang dapat berupa Peraturan perundang-undangan, dokumen, buku-buku, laporan, arsip, dan literatur yang berkaitan dengan masalah yang diteliti. Bahan hukum yang akan digunakan dalam penelitian ini adalah:

4.3.1. Bahan hukum primer

Bahan hukum primer yaitu bahan-bahan hukum pokok yang mengikat. Dalam penulisan ini, digunakan bahan hukum primer berupa :

4.3.1.1. Undang-Undang Nomor 8 Tahun 1999 tentang Perlindungan Konsumen.

4.3.1.2. Undang-Undang Nomor 10 Tahun 1998 tentang Perubahan Atas Undang-Undang Nomor 7 Tahun 1992 tentang Perbankan.

4.3.1.3. Peraturan Otoritas Jasa Keuangan Nomor 1/POJK.07/2013 tentang Perlindungan Konsumen Sektor Jasa Keuangan.

4.3.1.4. Peraturan Otoritas Jasa Keuangan Nomor 38 /POJK.03/2016 Tentang Penerapan Manajemen Risiko Dalam Penggunaan Teknologi Informasi Oleh Bank Umum.

\subsubsection{Bahan hukum sekunder}

Bahan hukum sekunder yaitu bahan-bahan hukum yang mendukung dan memperjelas bahan hukum primer yang berupa dokumen-dokumen resmi, meliputi karya tulis, buku-buku teks, jurnal-jurnal hukum dan komentar-komentar atas putusan pengadilan. 


\subsubsection{Bahan non-hukum}

Bahan yang memberikan penjelasan maupun petunjuk terhadap bahan hukum primer maupun sekunder yang telah ada seperti Kamus Besar Bahasa Indonesia dan lain sebagainya yang digunakan untuk mencari istilah-istilah dalam rangka menjelaskan hal-hal yang digunakan dalam bahan hukum primer maupun bahan hukum sekunder.

\subsection{Teknik Pengumpulan Data}

Teknik Pengumpulan data yang akan digunakan dalam penelitian hukum ini adalah studi kepustakaan yang terbatas pada penggunaan dokumen dan bahan pustaka. Pengumpulan data dilakukan dengan cara mengumpulkan data-data tertulis yang berkaitan dengan masalah yang diteliti.

\subsection{Metode Analisis Data}

Terkait dengan metode analisis bahan hukum yang digunakan dalam tulisan ini menggunakan metode deduktif, yaitu berpangkal dari prinsipprinsip dasar kemudian menghadirkan objek yang hendak diteliti, dengan kata lain, berpangkal dari prinsip-prinsip umum menuju prinsip-prinsip khusus. $^{21}$

\section{Pembahasan Penelitian dan Analisa}

\subsection{Bank dan produk Electronic Banking (E-Banking)}

Bank berasal dari kata italia banco yang artinya bangku. ${ }^{22}$ Bangku inilah yang dipergunakan oleh bangkir untuk melayani kegiatan operasionalnya kepada para nasabah. ${ }^{23}$ Istilah bangku secara resmi dan popular menjadi bank. Bank adalah lembaga keuangan yang menjadi tempat bagi orang perseorangan, badan-badan usaha swasta, badan-badan usaha milik negara, bahkan lembaga-lembaga pemerintahan menyimpan

\footnotetext{
${ }^{21}$ Ibid., hlm.42.

22 Fransisca Claudya Mewoh, dkk, "Analisis Kredit Macet”, Jurnal Administrasi Bisnis, ${ }^{23} \mathrm{Ibid}$.
} hlm. 2 
dana-dana yang dimilikinya. ${ }^{24}$ Dalam Kamus Besar Bahasa Indonesia, bank adalah usaha di bidang keuangan yang menarik dan mengeluarkan uang di masyarakat, terutama memberikan kredit dan jasa di lalu lintas pembayaran dan peredaran uang. ${ }^{25}$

Menurut ketentuan Pasal 1 Angka 2 Undang-Undang Nomor 10 Tahun 1998 tentang Perubahan Atas Undang-Undang Nomor 7 Tahun 1992 tentang Perbankan, bank adalah badan usaha yang menghimpun dana dari masyarakat dalam bentuk simpanan dan menyalurkannya kepada masyarakat dalam bentuk kredit dan/atau bentuk-bentuk lainnya dalam rangka meningkatkan taraf hidup rakyat banyak. Kemudian agar masyarakat mau menyimpan uangnya di bank maka pihak perbankan memberikan rangsangan berupa balas jasa yang akan diberikan kepada si penyimpan. ${ }^{26}$ Balas jasa tersebut dapat berupa bunga, bagi hasil, hadiah, pelayanan atau balas jasa lainnya. ${ }^{27}$ Setelah memperoleh dana dalam bentuk simpanan dari masyarakat, maka oleh perbankan, dana tersebut diputar kembali atau dijualkan kembali ke masyarakat dalam bentuk pinjaman atau lebih dikenal dengan istilah kredit, dan juga dikenakan jasa pinjaman kepada penerima kredit dalam bentuk bunga dan biaya administrasi yang besarnya dipengaruhi besarnya bunga simpanan. ${ }^{28}$

Sedangkan menurut G.M. Verryn Stuart, bank adalah suatu badan yang bertujuan untuk memuaskan kebutuhan kredit, baik dengan alat-alat pembayarannya sendiri atau dengan uang yang diperolehnya dari orang lain, maupun dengan jalan mengedarkan alat-alat penukar baru berupa uang giral. ${ }^{29}$ Kasmir mengartikan bank secara sederhana sebagai lembaga keuangan yang kegiatan utamanya adalah menghimpun dana dari masyarakat dan menyalurkan kembali dana tersebut kepada masyarakat

${ }^{24}$ Hermansyah, Hukum Perbankan Nasional Indonesia, Jakarta, Kencana Prenada Media Group, 2013, hlm. 7

${ }^{25}$ Ibid, hlm. 7-8.

${ }^{26}$ Kasmir, Bank dan Lembaga Keuangan Lainnya, Jakarta, PT Raja Grafindo Persada, 2015, hlm. 25

${ }^{27}$ Ibid.

${ }^{28}$ Ibid.

${ }^{29}$ Hermansyah, op cit, hlm. 8. 
serta memberikan jasa bank lainnya. ${ }^{30}$ Kemudian menurut A Abdurrachman, bank adalah suatu jenis lembaga keuangan yang melaksanakan berbagai macam jasa, seperti memberikan pinjaman, mengedarkan mata uang, pengawasan terhadap mata uang, bertindak sebagai tempat penyimpanan benda-benda berharga, membiayai usaha perusahaan-perusahaan, dan lain-lain. ${ }^{31}$

Menurut ketentuan Pasal 1 angka 3 Peraturan Otoritas Jasa Keuangan Nomor 38 /POJK.03/2016 Tentang Penerapan Manajemen Risiko Dalam Penggunaan Teknologi Informasi Oleh Bank Umum, Layanan Perbankan Elektronik (Electronic Banking atau e-banking) adalah layanan bagi nasabah Bank untuk memperoleh informasi, melakukan komunikasi, dan melakukan transaksi perbankan melalui media elektronik.

Kemudian menurut ketentuan Pasal 1 angka 3 Peraturan Bank Indonesia Nomor 9/15/PBI/2007 Tahun 2007 tentang Penerapan Manajemen Risiko Dalam Penggunaan Teknologi Informasi Oleh Bank Umum, layanan perbankan melalui media elektronik atau selanjutnya disebut electronic banking (biasa disebut juga dengan e-banking) adalah layanan yang memungkinkan nasabah Bank untuk memperoleh informasi, melakukan komunikasi, dan melakukan transaksi perbankan melalui media elektronik antara lain ATM, phone banking, electronic fund transfer, internet banking, mobile phone.

Adapun jenis-jenis produk e-banking yang sudah diterapkan di bank yang ada di Indonesia meliputi: ${ }^{32}$

5.1.1. Internet Banking

Ini termasuk layanan e-banking yang memungkinkan nasabah melakukan transaksi via internet dengan menggunakan Personal Computer atau PC atau PDA.

\footnotetext{
${ }^{30}$ Kasmir, Analisis Laporan Keuangan, Jakarta, Rajawali Pers, 2008, hlm. 11.

31 A. Abdurrachman, Ensiklopedi Ekonomi Keuangan Perdagangan. Jakarta, Pradnya Paramita, 1993, hlm. 80.

${ }^{32}$ https://www.it-jurnal.com/pengertian-e-banking, diakses pada tanggal 20 Agustus 2018
} 
Fitur transaksi yang dapat dilakukan sama dengan Phone Banking yaitu informasi jasa atau produk bank, informasi saldo rekening, transaksi pemindahbukuan antar rekening, pembayaran (kartu kredit, listrik, dan telepon), pembelian (voucher dan tiket), dan transfer ke bank lain. Kelebihan dari saluran ini adalah kenyamanan bertransaksi dengan tampilan menu dan informasi secara lengkap tertampang di layar komputer/PC atau PDA.

\subsubsection{SMS Banking}

Layanan ini pada dasarnya evolusi lebih lanjut dari Phone Banking, yang memungkinkan nasabah untuk bertransaksi via Handphone (HP) dengan perintah SMS. Fitur transaksi yang dapat dilakukan yaitu informasi saldo rekening, pemindahbukuan antar rekening, pembayaran (kartu kredit, listrik, dan telepon), dan pembelian voucher.

\subsubsection{Phone Banking}

Ini adalah layanan yang memungkinkan nasabah untuk melakukan transaksi dengan bank via telepon. Pada awalnya lazim diakses melalui telepon rumah, namun seiring dengan makin populernya telepon genggam atau Handphone (HP), maka tersedia pula nomor akses khusus via Handphone (HP) bertarif panggilan flat dari manapun nasabah berada.

\subsubsection{ATM (Automated Teller Machine)}

Automated Teller Machine atau Anjungan Tunai Mandiri atau lebih singkatnya disebut ATM, ini adalah saluran $e$ banking paling populer. Hampir setiap orang pasti mempunyai kartu ATM dan menggunakan fasilitas ATM. Fitur tradisional ATM adalah untuk mengetahui informasi saldo dan melakukan penarikan tunai. Dalam perkembangannya, fitur semakin bertambah yang 
memungkinkan untuk melakukan pemindahbukuan antar rekening, pembayaran (kartu kredit, listrik, dan telepon), pembelian (voucher dan tiket), dan yang terkini transfer ke bank lain (dalam satu switching jaringan ATM).

Selain itu bagi nasabah dapat menikmati fasilitas atau layanan kartu kredit. Berdasarkan ketentuan Pasal 1 angka 4 Peraturan Bank Indonesia Nomor 14/2/PBI/2012 tentang Perubahan Atas Peraturan Bank Indonesia Nomor 11/11/PBI/2009 Tentang Penyelenggaraan Kegiatan Alat Pembayaran Dengan Menggunakan Kartu, Kartu Kredit adalah alat pembayaran dengan menggunakan kartu (APMK) yang dapat digunakan untuk melakukan pembayaran atas kewajiban yang timbul dari suatu kegiatan ekonomi, termasuk transaksi pembelanjaan dan/atau untuk melakukan penarikan tunai, dimana kewajiban pembayaran pemegang kartu dipenuhi terlebih dahulu oleh acquirer atau penerbit, dan pemegang kartu berkewajiban untuk melakukan pembayaran pada waktu yang disepakati baik dengan pelunasan secara sekaligus (charge card) ataupun dengan pembayaran secara angsuran.

\subsection{Pengaturan Perlindungan Hukum Nasabah Perbankan dalam Transaksi E-Banking}

Bertitik tolak dari luas dan kompleksnya hubungan antara produsen dan konsumen, serta banyaknya mata rantai penghubung keduanya, maka untuk melindungi konsumen sebagai pemakai akhir barang atau jasa membutuhkan berbagai aspek hukum agar benar-benar dapat dilindungi dengan adil. ${ }^{33}$ Sejak awal nasabah harus benar-benar dilindungi ketika menggunakan produk dan/atau jasa yang ditawarkan oleh pihak bank. Sehingga nasabah tidak akan mengalami kerugian finansial. Bank Indonesia sebagai pelaksana otoritas moneter mempunyai peranan yang besar dalam usaha melindungi, dan menjamin agar nasabah tidak mengalami kerugian akibat tindakan bank yang salah.

\footnotetext{
${ }^{33}$ Ali Murdiat, op. cit, hlm. 62.
} 
Hal-hal yang menyangkut dengan usaha perlindungan nasabah diantaranya berupa laporan dan data-data yang merupakan bahan informasi. ${ }^{34}$ Mengingat pentingnya perlindungan nasabah tersebut, Bank Indonesia menetapkan upaya perlindungan nasabah sebagai salah satu pilar dalam Arsitektur Perbankan Indonesia (API). ${ }^{35}$ API merupakan suatu kerangka dasar sistem perbankan Indonesia yang terdiri dari enam pilar, bersifat menyeluruh dan memberikan arah, bentuk dan tatanan pada industri perbankan untuk rentang waktu lima sampai sepuluh tahun ke depan. $^{36}$

\subsubsection{Perlindungan Hukum Preventif}

Dalam Peraturan Otoritas Jasa Keuangan Nomor 1/POJK.07/2013 tentang Perlindungan Konsumen Sektor Jasa Keuangan yaitu dalam Pasal 25, Pasal 27, Pasal 29 disebutkan tentang kewajiban Pelaku Usaha Jasa Keuangan, yaitu:

Pasal 25 : "Pelaku Usaha Jasa Keuangan wajib menjaga keamanan simpanan, dana, atau asset konsumen yang berada dalam tanggung jawab Pelaku Usaha Jasa Keuangan".

Pasal 27 : "Pelaku Usaha Jasa Keuangan wajib memberikan laporan kepada Konsumen tentang posisi saldo dan mutasi simpanan, dana, asset, atau kewajiban Konsumen secara akurat, tepat waktu, dan dengan cara atau sarana sesuai dengan perjanjian dengan Konsumen".

Pasal 29 : "Pelaku Usaha Jasa Keuangan wajib bertanggung jawab atas kerugian Konsumen yang timbul akibat kesalahan dan/atau kelalaian, pengurus, pegawai Pelaku Usaha Jasa Keuangan dan/atau pihak ketiga yang bekerja untuk kepentingan Pelaku Usaha Jasa Keuangan".

\footnotetext{
${ }^{34}$ Ibid, hlm. 63.

${ }^{35}$ Ibid.

${ }^{36}$ Ibid.
} 
Dalam Pasal 23 Peraturan Otoritas Jasa Keuangan Nomor 38 /POJK.03/2016 Tentang Penerapan Manajemen Risiko Dalam Penggunaan Teknologi Informasi Oleh Bank Umum disebutkan bahwa :

(1) Bank wajib menyelenggarakan Pemrosesan Transaksi Berbasis Teknologi Informasi di wilayah Indonesia.

(2) Pemrosesan Transaksi Berbasis Teknologi Informasi dapat dilakukan oleh pihak penyedia jasa di wilayah Indonesia.

(3) Penyelenggaraan Pemrosesan Transaksi Berbasis Teknologi Informasi oleh pihak penyedia jasa sebagaimana dimaksud pada ayat (2) dapat dilakukan sepanjang:

a. Memenuhi prinsip kehati-hatian;

b. Memenuhi persyaratan sebagaimana dimaksud dalam Pasal 20 ayat (3), ayat (4), dan ayat (5); dan

c. Memperhatikan aspek perlindungan kepada nasabah.

(4) Pemrosesan Transaksi Berbasis Teknologi Informasi oleh pihak penyedia jasa Teknologi Informasi dapat dilakukan di luar wilayah Indonesia sepanjang:

a. Memenuhi persyaratan sebagaimana dimaksud pada ayat (3);

b. Dokumen pendukung administrasi keuangan atas transaksi yang dilakukan di kantor Bank di Indonesia wajib ditatausahakan di kantor Bank di Indonesia;

c. Rencana bisnis Bank menunjukkan adanya upaya untuk meningkatkan peran Bank bagi perkembangan perekonomian Indonesia; dan

d. Mendapatkan persetujuan terlebih dahulu oleh Otoritas Jasa Keuangan.

Kemudian dalam Pasal 29 disebutkan bahwa :

"Bank wajib menerapkan prinsip pengendalian pengamanan data nasabah dan transaksi Layanan Perbankan Elektronik pada setiap Sistem Elektronik yang digunakan oleh Bank”.

Pasal 27 ayat (1) Peraturan Bank Indonesia Nomor 16/1/PBI/2014 tentang Perlindungan Konsumen Jasa Sistem Pembayaran menyebutkan hahwa penyelenggara wajib memberikan informasi mengenai manfaat, risiko, dan konsekuensi bagi Konsumen atas penggunaan jasa Sistem Pembayaran. 
Kemajuan ilmu pengetahuan dan teknologi saat ini meningkatkan kemungkinan terjadinya kerugian finansial yang dialami oleh nasabah. Undang-Undang Nomor 8 Tahun 1999 tentang Perlindungan Konsumen yaitu dalam Pasal 4 huruf a jelas menyebutkan bahwa konsumen mempunyai hak atas kenyamanan, keamanan, dan keselamatan dalam mengkonsumsi barang dan/atau jasa. Selain itu dalam Pasal 29 ayat (4) Undang-Undang Nomor 10 Tahun 1998 tentang Perubahan Atas Undang-Undang Nomor 7 Tahun 1992 tentang Perbankan juga disebutkan, untuk kepentingan nasabah, bank menyediakan informasi mengenai kemungkinan timbulnya risiko kerugian bagi transaksi nasabah yang dilakukan melalui bank.

Dalam rangka penyelenggaraan layanan perbankan elektronik bagi nasabah maka bank akan memberikan edukasi kepada setiap nasabahnya. Khusus untuk program edukasi nasabah, pelaksanaannya dirasakan perlu diperluas hingga mencakup mereka yang belum dan akan menjadi nasabah bank agar pada saat pertama kali berhubungan dengan bank para calon nasabah tersebut sudah memiliki informasi yang cukup mengenai kegiatan usaha serta produk dan jasa bank. ${ }^{37}$ Edukasi masyarakat dibidang perbankan pada dasarnya merupakan pemberian informasi dan pemahaman kepada masyarakat mengenai fungsi dan kegiatan usaha bank, serta produk dan jasa yang ditawarkan bank. ${ }^{38}$ Pemberian Edukasi ini diharapkan dapat memfasilitasi pemberian informasi yang cukup kepada masyarakat sebelum mereka melakukan interaksi dengan bank. ${ }^{39}$ Dengan demikian akan terhindar adanya kesenjangan informasi pada pemanfaatan produk

\footnotetext{
${ }^{37}$ Ibid.

${ }^{38}$ Ibid.

${ }^{39}$ Ibid.
} 
dan jasa perbankan yang dapat menyebabkan timbulnya permasalahan antara bank dengan nasabah dikemudian hari. ${ }^{40}$

Dalam rangka perlindungan konsumen, Undang-Undang Nomor 11 Tahun 2008 tentang Informasi dan Transaksi Elektronik mengatur adanya teknologi netral yang dipergunakan dalam transaksi elektronik, serta mensyaratkan adanya kesepakatan penggunaan sistem elektronik yang dipergunakan. ${ }^{41}$ Selain itu dalam ketentuan Pasal 15 Undang-Undang Nomor 11 Tahun 2008 tentang Informasi dan Transaksi Elektronik disebutkan bahwa setiap penyelenggara sistem elektronik diwajibkan untuk menyediakan sistem elektronik secara handal dan aman serta bertanggung jawab terhadap beroperasinya sistem elektronik sebagaimana mestinya. Penyelenggara sistem elektronik bertanggung jawab terhadap penyelenggaraan sistem elektroniknya. Namun ketentuan tersebut tidak berlaku dalam hal dapat dibuktikan terjadinya keadaan memaksa, kesalahan, dan/atau kelalaian pihak pengguna sistem elektronik.

Dalam rangka memberikan perlindungan dan keamanan bagi penyelenggaraan kegiatan transaksi elektronik, sejalan dengan Undang-Undang Nomor 11 Tahun 2008 tentang Informasi dan Transaksi Elektronik, Bank Indonesia telah menerbitkan berbagai peraturan (regulasi) terkait penggunaan teknologi informasi bagi perbankan dan lembaga penyelenggara sistem pembayaran dalam bentuk Peraturan Bank Indonesia dan Surat Edaran Bank Indonesia. Peraturan tersebut antara lain ditujukan untuk meningkatkan keamanan, integritas data, dan ketersediaan layanan e-banking. Seperti yang tertuang dalam Pasal 29A Peraturan Bank Indonesia Nomor 14/2/PBI/2012 tentang Perubahan Atas Peraturan Bank Indonesia Nomor 11/11/PBI/2009 tentang Penyelenggaraan

\footnotetext{
${ }^{40}$ Ibid.

${ }^{41}$ Ibid.
} 
Kegiatan Alat Pembayaran Dengan Menggunakan Kartu yang menentukan dalam rangka peningkatan keamanan transaksi, Penerbit Kartu wajib mengimplementasikan transaction alert kepada Pemegang Kartu untuk transaksi dengan kriteria tertentu. Dalam penjelasan Pasal 29A tersebut disebutkan bahwa yang dimaksud dengan transaction alert adalah pesan yang disampaikan Penerbit kepada Pemegang Kartu Kredit mengenai transaksi Kartu Kredit yang perlu diketahui oleh Pemegang Kartu Kredit untuk memastikan bahwa transaksi tersebut benar-benar dilakukan oleh Pemegang Kartu yang bersangkutan. Selain itu penerbit kartu biasanya menggunakan chip pada kartu-kartu pembayarannya.

\subsubsection{Perlindungan Hukum Represif}

Permasalahan antara bank dengan nasabah lebih kepada permasalahan keperdataan dan kerugian yang ditimbulkan juga kerugian finansial sehingga untuk menyelesaikannya, perlu ada jaminan penggantian kerugian yang dialami nasabah. Dalam ketentuan Pasal 4 huruf h Undang-Undang Nomor 8 Tahun 1999 tentang Perlindungan Konsumen disebutkan bahwa konsumen mempunyai hak untuk mendapatkan kompensasi, ganti rugi dan/atau penggantian, apabila barang dan/atau jasa yang diterima tidak sesuai dengan perjanjian atau tidak sebagaimana mestinya. Oleh karena itu Nasabah sebagai konsumen produk dan/atau jasa yang ditawarkan bank sebagai produsen berhak atas penggantian kerugian yang dialami ketika melakukan transaksi dengan fasilitas atau layanan $e$-banking. Bank wajib memberikan ganti rugi kepada nasabah selaku konsumen jasa perbankan atas kerugian dari penggunaan e-banking yang disediakan bank.

Namun perlu diperhatikan bahwa ketentuan ini tidak berlaku apabila nasabah menderita kerugian yang dikarenakan oleh tindakan atau kelalaian nasabah yang sebelumnya telah 
diperingatkan atau diedukasi oleh bank. Hal ini sesuai dengan ketentuan Pasal 19 Undang-Undang Nomor 8 Tahun 1999 tentang Perlindungan Konsumen yang menyebutkan Pelaku usaha (dalam hal ini bank) bertanggung jawab memberikan ganti rugi atas kerusakan, pencemaran, dan atau kerugian konsumen akibat mengkonsumsi barang dan atau jasa yang dihasilkan atau diperdagangkan, ganti kerugian tersebut berupa pengembalian uang yang nilainya setara dengan kerugian yang ditimbulkan, serta ketentuan Pasal 29 Peraturan Otoritas Jasa Keuangan Nomor 1/POJK.07/2013 tentang Perlindungan Konsumen Sektor Jasa Keuangan yang menyebutkan bahwa Pelaku Usaha Jasa Keuangan wajib bertanggung jawab atas kerugian Konsumen yang timbul akibat kesalahan dan/atau kelalaian, pengurus, pegawai Pelaku Usaha Jasa Keuangan dan/atau pihak ketiga yang bekerja untuk kepentingan Pelaku Usaha Jasa Keuangan.

\subsection{Penyelesaian Sengketa Antara Bank dan Nasabah dalam Transaksi E-Banking}

Jika nasabah dirugikan dalam penggunaan e-banking, hal pertama yang harus dilakukan oleh nasabah adalah melaporkannya kepada pihak bank. Kemudian pihak bank akan menyelesaikannya karena penyelesaian pengaduan nasabah merupakan satu bentuk peningkatan perlindungan nasabah dalam rangka menjamin hak-hak nasabah dalam berhubungan dengan bank. Pengaduan nasabah yang tidak segera ditindaklanjuti berpotensi meningkatkan risiko reputasi bagi bank dan dalam jangka panjang dapat menurunkan kepercayaan masyarakat terhadap lembaga perbankan. Di setiap bank sendiri wajib memiliki unit dan atau fungsi yang dibentuk secara khusus di setiap kantor bank untuk menangani dan menyelesaiakan pengaduan yang diajukan oleh nasabah dan/atau perwakilan nasabah. 
Proses penyelesaian sengketa antara bank dengan nasabah baik nasabah debitur maupun nasabah kreditur diatur dalam Undang-Undang Nomor 8 Tahun 1999 tentang Perlindungan Konsumen Jo. Keputusan Menteri Perindustrian dan Perdagangan Republik Indonesia Nomor 350/MPP/Kep/12/2001 tentang Pelaksanaan Tugas dan Wewenang Badan Penyelesaian Sengketa Konsumen, Peraturan Bank Indonesia Nomor 10/ 10 /PBI/2008 tentang Perubahan Atas Peraturan Bank Indonesia Nomor 7/7/PBI/2005 tentang Penyelesaian Pengaduan Nasabah dan Peraturan Otoritas Jasa Keuangan Nomor 1/POJK.07/2013 tentang Perlindungan Konsumen Sektor Jasa Keuangan.

Namun sekarang terdapat Peraturan Otoritas Jasa Keuangan Nomor 1/POJK.07/2104 tentang Lembaga Alternatif Penyelesaian Sengketa di Sektor Jasa Keuangan. Peraturan OJK tersebut menjadi dasar dibentuknya Lembaga Alternatif Penyelesaian Sengketa di Sektor Jasa Keuangan. Kemudian untuk sektor perbankan terdapat Lembaga Alternatif Penyelesaian Sengketa Perbankan Indonesia. Berdirinya Lembaga Alternatif Penyelesaian Sengketa Perbankan Indonesia merupakan suatu kewajiban. Lembaga Alternatif Penyelesaian Sengketa Perbankan Indonesia atau biasa disingkat LAPSPI dibentuk oleh asosiasi bidang perbankan dan didaftarkan di OJK. LAPSPI sendiri menyediakan tiga layanan penyelesaian sengketa yaitu mediasi, ajudikasi dan arbitrase. Dengan telah beroperasinya LAPSPI sejak Januari 2016 maka penanganan pengaduan yang masuk melalui Financial Costumer Care (FCC) OJK sebatas verifikasi dan klarifikasi. ${ }^{42}$

Dalam Siaran Pers Nomor SP 77/DKNS/OJK/8/2016 dijelaskan bahwa Otoritas Jasa Keuangan terus melakukan pengawasan terhadap pelaksanaan penanganan pengaduan yang dilaporkan melalui Sistem Pelaporan Edukasi dan Perlindungan Konsumen (SIPEDULI) untuk monitoring pengaduan yang masuk, diproses dan diselesaikan oleh

${ }^{42}$ http://infobanknews.com/ojk-6-lembaga-penyelesaian-sengketa-siap-beroperasi/, diunduh pada hari Senin, 30 Januari 2017, pukul 14.40 WIB. 
Internal Dispute Resolution (IDR) Pelaku Usaha Jasa Keuangan (PUJK). Siaran Pers tersebut juga memuat pendapat Anggota Dewan Komisioner OJK bidang Edukasi dan Perlindungan Konsumen, Kusumaningtuti S Setiono, bahwa Pelaksanaan IDR merupakan pelaksanaan POJK Nomor 1/2013 tentang Perlindungan Konsumen di Sektor Jasa Keuangan dan PUJK meresponnya dengan membentuk unit dan/atau fungsi pengaduan dan memiliki service level agreement sehingga konsumen merasa terlindungi dengan baik.

Terhadap beberapa kasus penanganan pengaduan yang tidak selesai dengan PUJK, OJK mendorong masyarakat untuk meneruskannya kepada LAPSI dengan tahapan proses yang dapat dilalui meliputi mediasi, ajudikasi dan arbitrase. Berdasarkan Data sejak Januari s.d. Juni 2016 yang dimuat dalam Siaran Pers Nomor SP 77/DKNS/OJK/8/2016, LAPSPI telah menerima sembilan kasus sengketa industri perbankan selama periode Januari hingga Juni 2016. Dari kasus-kasus tersebut, sebanyak enam kasus dinyatakan sudah selesai dan tiga lainnya dalam proses penyelesaian. Kasus sengketa yang diterima oleh LAPSPI terlebih dahulu harus diselesaikan secara internal oleh nasabah dan bank atau Internal Dispute Resolution (IDR). ${ }^{43}$

\section{Kesimpulan}

Perlindungan hukum bagi nasabah dalam transaksi e-banking dapat dibedakan menjadi dua yaitu perlindungan hukum preventif dan represif. Perlindungan Hukum Preventif yang diberikan kepada nasabah bertujuan untuk mencegah sebelum terjadinya kerugian dalam melakukan transaksi $e$ banking, perlindungan hukum preventif belum diatur secara khusus namun dapat mengaitkannya dengan berbagai peraturan yang menentukan kewajiban pelaku usaha jasa keuangan dimana dalam hal ini adalah bank, seperti Peraturan Otoritas Jasa Keuangan Nomor 1/POJK.07/2013 tentang Perlindungan Konsumen Sektor Jasa Keuangan, Peraturan Bank Indonesia

\footnotetext{
${ }^{43}$ Ibid.
} 
Nomor 16/1/PBI/2014 tentang Perlindungan Konsumen Jasa Sistem Pembayaran, Undang-Undang Nomor 8 Tahun 1999 tentang Perlindungan Konsumen. Seluruh peraturan hukum tersebut secara parsial memberikan perlindungan hukum preventif terhadap nasabah dalam melakukan transaksi $e$ banking.

Kemudian perlindungan hukum preventif mengatur Nasabah sebagai konsumen produk dan/atau jasa yang ditawarkan bank sebagai produsen berhak atas penggantian kerugian yang dialami ketika melakukan transaksi dengan fasilitas atau layanan e-banking. Bank wajib memberikan ganti rugi kepada Nasabah selaku konsumen jasa perbankan atas kerugian dari penggunaan e-banking yang disediakan bank. Namun perlu diperhatikan bahwa ketentuan ini tidak berlaku apabila nasabah menderita kerugian yang dikarenakan oleh tindakan atau kelalaian nasabah yang sebelumnya telah diperingatkan atau diedukasi oleh bank.

Mengenai penyelesaian sengketa Penyelesaian masalah antara nasabah dapat dilakukan dengan cara negosiasi dan saat ini ada Lembaga Alternatif Penyelesian Sengketa Perbankan Indonesia (LAPSPI) yang mempunyai layanan penyelesian berupa mediasi, ajudikasi dan arbitrase. Namun jika alternatif penyelesaian sengketa gagal, Bank masih melaporkannya ke OJK dan Pengadilan menjadi pilihan terakhir. 


\section{DAFTAR PUSTAKA}

\section{Peraturan Perundang-Undangan}

Kitab Undang-Undang Hukum Perdata Buku III tentang Perikatan

Undang-Undang Nomor 10 Tahun 1998 tentang Perubahan Atas UndangUndang Nomor 7 Tahun 1992 tentang Perbankan.

Undang-Undang Nomor 8 Tahun 1999 tentang Perlindungan Konsumen.

Undang-Undang Nomor 37 Tahun 2004 tentang Kepailitan dan Penundaan Kewajiban Pembayaran Utang.

Undang-Undang Nomor 11 Tahun 2008 tentang Informasi dan Transaksi Elektronik.

Keputusan Menteri Perindustrian dan Perdangan Republik Indonesia Nomor 350/MPP/Kep/12/2001 tentang Pelaksanaan Tugas dan Wewenang Badan Penyelesaian Sengketa Konsumen.

Peraturan Otoritas Jasa Keuangan Nomor 1/POJK.07/2013 tentang Perlindungan Konsumen Sektor Jasa Keuangan.

Peraturan Otoritas Jasa Keuangan Nomor 1/POJK.07/2104 tentang Lembaga Alternatif Penyelesaian Sengketa di Sektor Jasa Keuangan.

Peraturan Otoritas Jasa Keuangan Nomor 38 /POJK.03/2016 tentang Penerapan Manajemen Risiko Dalam Penggunaan Teknologi Informasi Oleh Bank Umum.

Peraturan Bank Indonesia Nomor 10/ 10 /PBI/2008 tentang Perubahan Atas Peraturan Bank Indonesia Nomor 7/7/PBI/2005 tentang Penyelesaian Pengaduan Nasabah.

Peraturan Bank Indonesia Nomor Nomor 14/2/PBI/2012 tentang Perubahan

Atas Peraturan Bank Indonesia Nomor 11/11/PBI/2009 tentang Penyelenggaraan Kegiatan Alat Pembayaran Dengan Menggunakan Kartu.

Peraturan Bank Indonesia Nomor 16/1/PBI/2014 tentang Perlindungan Konsumen Jasa Sistem Pembayaran.

Peraturan Lembaga Alternatif Penyelesaian Sengketa Perbankan Indonesia Nomor 07/LAPSPI-PER/2015 tentang Peraturan dan Prosedur Mediasi.

Peraturan Lembaga Alternatif Penyelesaian Sengketa Perbankan Indonesia Nomor 08/LAPSPI-PER/2015 tentang Peraturan dan Prosedur Ajudikasi.

Peraturan Lembaga Alternatif Penyelesaian Sengketa Perbankan Indonesia Nomor 09/LAPSPI-PER/2015 tentang Peraturan dan Prosedur Arbitrase. 


\section{Literatur Ilmiah}

A Abdurrachman, Ensiklopedi Ekonomi Keuangan Perdagangan, Jakarta, Pradnya Paramita, 1993.

Departemen Pendidikan dan Budaya, Kamus Besar Bahasa Indonesia Buku Satu, Jakarta, Balai Pustaka Utama, 1989.

Dewi, Eli Wuria, Hukum Perlindungan Konsumen, Yogyakarta, Graha Ilmu, 2015.

Djumhana, Muhammad, Azas-Azas Hukum Perbankan Indonesia, Bandung, Citra Aditya Bakti, 2008.

Fransisca Claudya Mewoh, dkk, "Analisis Kredit Macet”, Jurnal Administrasi Bisnis.

Gunawan Widjaja dan Ahmad Yani, Hukum Tentang Perlindungan Konsumen, Jakarta, PT Gramedia Pustaka Utama, 2003.

Hermansyah, Hukum Perbankan Nasional Indonesia, Jakarta, Kencana Prenada Media Group, 2013.

Kasmir, Analisis Laporan Keuangan, Jakarta, Rajawali Pers, 2008.

-------, Dasar-Dasar Perbankan, Jakarta, PT. Raja Grafindo Persada, 2015.

Kusuma, Mahesa Jati, Hukum Perlindungan Nabah Bank : Upaya Hukum Melindungi Nasabah Bank Terhadap Tindak Kejahatan ITE di Indonesia, Jakarta, Nusa Media, 2012.

M Hadjon, Philipus, Perlindungan Hukum bagi Rakyat Indonesia. Surabaya, Bina Ilmu, 1987.

Mertokusumo, Sudikno, Mengenal Hukum Suatu Pengantar, Yogyakarta, Cahaya Atma Pustaka, 2010.

Murdiat, Ali, "Perlindungan Hukum Nasabah Pengguna Elektronik Banking Dalam Sistem Hukum Indonesia", Volume I Nomor I, April-Juni, 2013.

ND, Mukti. Fajar, dan Achmad, Yulianto, Dualisme Penelitian Hukum Normatif \& Empiris, Yogyakarta: Pustaka Pelajar, 2010.

Simanjuntak, Diana, "Tinjauan Hukum Perlindungan Konsumen Terhadap Perjanjian Kredit Bank", Volume IV Nomor I, 2016.

Soetarto dan M Nasir, "Teknologi E-Banking di Kalangan Smart Customer : Kasus di Kota Solo", Paper Conference Fakultas Ekonomi Universitas Muhammadiyah Solo, 2008.

Sjahdeni, Sutan Remy, Kebebasan Berkontrak Dan Perlindungan Yang Seimbang Bagi Para Pihak Dalam Perjanjian Kredit Bank di Indonesia, Jakarta, PT Pustaka Utama Grafitri, 2009. 


\section{Media Online}

http://bisniskeuangan.kompas.com/read/2015/04/15/113500326/Ini.Modus.Pe mbobolan.Rekening.Nasabah.Melalui.e-Banking, diakses pada tanggal 19 Agustus 2018

http://bisniskeuangan.kompas.com/read/2015/03/04/144553726/BCA.Minta.N asabah.Waspadai.Sinkronisasi.Token.saat.Membuka.Internet.Banking , diakses pada tanggal 19 Agustus 2018

http://www.cnnindonesia.com/ekonomi/20150306103528-78-37161/rekeningdibobol-kasus-bank-permata-lanjut-di-pengadilan/, diakses pada tanggal 19 Agustus 2018 